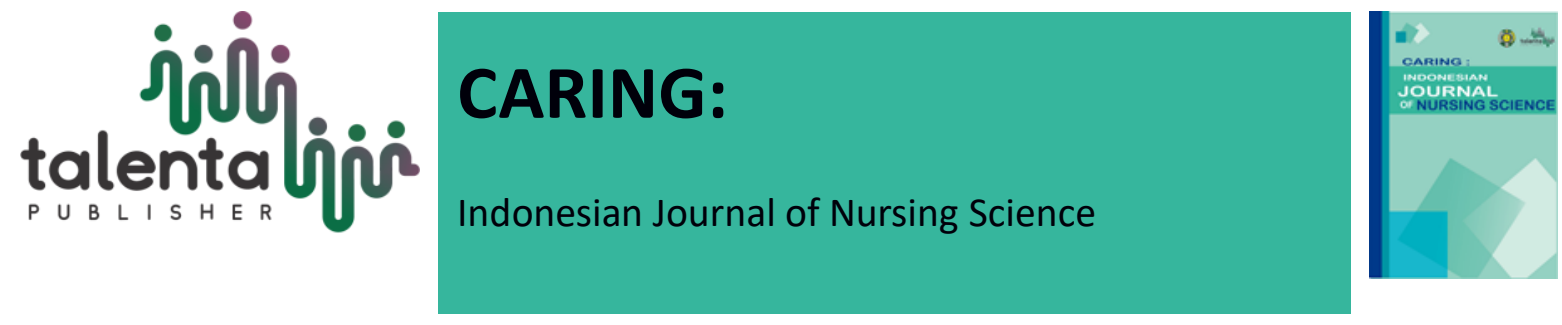

\title{
Knowledge and Attitudes of Families Regarding Elderly Fall Prevention in Pahlawan Binjai Village
}

\author{
Indra Agussamad, Zuraidah, Rosmega, Zulkarnain Batubara
}

STIKes Mitra Husada Medan - Indonesia

\begin{abstract}
Knowledge is the result of know that going after someone makes a sensing of a particular object. While the attitude of the views or feelings that accompanied the tendency to act. If knowledge of a person's behavior, the better it would be even better. However, knowledge is either not accompanied with the attitude that knowledge would be meaningless. This study aims to describe a family of knowledge on the prevention of falls in older adults and family attitudes about the prevention of the incidence of falls in older adults at Kelurahan Pahlawan Binjai. This study was used a descriptive design with a purposive sampling technique involving 71 respondents conducted in April 2012. All respondents answered a questionnaire that was given to the respondents.
\end{abstract}

Keywords: Knowledge, Attitudes, Family, and Falls

Received 26 November 2020 | Revised 26 November 2020 | Accepted 31 December 2020

\section{Introduction}

When someone gets old they will experience the process of aging. ${ }^{1}$ The process of aging is a lifelong process, not only starting from a certain event, but starting from the beginning of life (Nugroho, 2008) .2 In entering old age there will be setbacks, for example a physical deterioration marked by sagging skin, white hair, teeth starting toothless, hearing is less clear, vision gets worse, movement is slow, and less agile (Maryam, Ekasari, Rosidawati, Jubaedi, Batubara, 2008) . ${ }^{3}$ The speed of the aging process for each individual in the organs of the body will not be the same. ${ }^{4}$ Sometimes a person is not classified as old / young but has shown significant deficiencies. ${ }^{5}$ There are also people who are classified as elderly, their appearance is still healthy, fit and well-built (Nugroho, 2008) . ${ }^{6}$

\footnotetext{
*Corresponding author at: STIKES Mitra Husada, Medan - Indonesia

Corresponding email: Syamsiarindra@gmail.com

Copyright $(\odot$ Published by Talenta Publisher, ISSN: 2580-6769 e-ISSN: 2580-829X

Journal Homepage: https://talenta.usu.ac.id/IJNS
} 
Elderly (seniors) is someone who has reached the age of more than 60 years (Law No.13 of 1998 in Maryam et al, 2008).$^{7}$ The development of the elderly population from year to year tends to increase. ${ }^{8}$ In 1980, life expectancy ( UHH) 52.2 years and the number of elderly $7,998,543$ people (5.45\%), then in 2006 it became 19 million people (8.90\%) and UHH also increased (66.2 years). In 2010, the number of elderly people living in urban areas was 12,380,321 (9.58\%) and those living in rural areas were $15,612,232(9.97 \%)$. Ten years later or in 2020, the estimated elderly population in Indonesia will reach 28.8 million or $11.34 \%$ with a UHH of around 71.1 years (Hamid, 2007). ${ }^{9}$

In the elderly there are many physical problems that often occur, one of which is falling (Nugroho, 2008). ${ }^{10}$ According to Reuben (1996 in Darmojo \& Martono, 2004) falling is an event that causes a person to suddenly lie / sit on the floor with or without losing consciousness or injury. ${ }^{11}$ There are many factors that cause falls, namely intrinsic factors that come from within the elderly themselves such as gait disorders. Meanwhile, extrinsic factors such as slippery and uneven floors. ${ }^{13}$ Approximately 30$50 \%$ of the elderly population aged 65 years and over experience a fall each year. ${ }^{14}$ Half of these numbers experience repeated falls (Nugroho, 2008). ${ }^{15}$ In the elderly over 80 years, about $50 \%$ have experienced falls. ${ }^{16}$ Although not all falls result in injury or require treatment, the incidence of injury due to falls also increases, especially at those above 85 years of age (Probosuseno, 2006). ${ }^{17}$

Fall cases that occurred in the RSCM elderly integrated service clinic in 2000 amounted to $15.53 \%$ (285 cases). ${ }^{18}$ In 2001, 15 elderly patients (out of 146 patients) were treated for instability and frequent falls. In 1999, 2000, and 2001, there were 25 patients, 31 patients, and 42 patients respectively who had to be treated for fractures of the femur due to falls (Supartondo, Setiati \& Soejono, 2003 in Maryam, et al. 2008). ${ }^{19}$ From these data, it can be concluded that the incidence of falls in the elderly is increasing from year to year. ${ }^{20}$ Therefore, efforts to prevent falls in the elderly are a step that needs to be done because if a fall has occurred, it will definitely cause complications, although mild it is still burdensome for the elderly's condition. (Darmojo \& Martono 2004).$^{21}$

In caring for the elderly, it cannot be done alone but must also involve family members. ${ }^{22}$ Family is the main support system for the elderly in maintaining their health. ${ }^{23}$ Families play an important role in caring for the elderly (Maryam, 2009). ${ }^{24}$ Caring for the elderly is not an easy job because this requires knowledge (Siburian, 2005 in Narayani, 2008). ${ }^{25}$

Knowledge is the result of knowing that occurs after a person senses a certain object (Notoatmodjo, 2003). ${ }^{26}$ Meanwhile, attitude is a view or feeling accompanied by a tendency to act (Purwanto, 1999). ${ }^{27}$ If a person's knowledge is getting better, his behavior will be more good. ${ }^{28}$ However, good knowledge is not accompanied by an attitude so that knowledge will not be meaningful (Notoatmojo, 2003). ${ }^{29}$ 
Susanti (2009) in her research on the relationship between the level of family knowledge and the attitudes of elderly families in fall prevention, found that most families have good knowledge and most of the attitudes of families regarding the prevention of old age falls at home are in the sufficient category. ${ }^{31}$ Attitude formation does not occur automatically easy but requires a process. ${ }^{32}$ The factors that influence attitudes, namely factors from within the individual itself such as selectivity and external factors such as the communication media used in conveying attitudes (Purwanto, 1999). ${ }^{33}$

Pahlawan Kelurahan, Binjai Utara District, has a population of around 11,068 people consisting of 706 elderly people with the classification of 311 men and 395 women, both those who live with their families and those who do not live with their families (Lumbantoruan, 2010). ${ }^{34}$

Based on a preliminary survey conducted by researchers in November 2011 in Pahlawan Binjai Village towards 5 families, that 3 out of 5 families did not know about fall prevention while 2 other families knew about fall prevention but the 2 families ignored fall prevention efforts. ${ }^{35}$ Based on this preliminary research and from the description above, the researcher is interested in researching the knowledge and attitudes of the family regarding the prevention of falls in the elderly in Pahlawan Binjai Village. ${ }^{36}$

\section{Research Method}

This study used a descriptive design that aims to obtain an overview of family knowledge and attitudes about the prevention of falls in the elderly in Pahlawan Binjai Village. ${ }^{37}$ The population taken in this study were families who had elderly men and women aged 60 years and over. ${ }^{38}$ obtained from Pahlawan Binjai Village, the number of elderly living in the kelurahan is 706 people where the elderly live in the same house as the family and there are also elderly people who do not live with their family but the elderly's family always visit the elderly. ${ }^{39}$ The number of samples in this study is the sample taken as much as $10 \%$ of the total population so that the sample in this study amounted to 71 families because considering the ability of researchers seen from limited costs,time, and energy. ${ }^{40}$ 


\section{Research Result and Discussion}

Table 1.Frequency distribution and percentage of characteristics of families living with elderly in Pahlawan Binjai Village in April $2012(\mathrm{~N}=71)$

\begin{tabular}{|c|c|c|c|}
\hline No. & Family Characteristics & $\mathrm{F}$ & $\%$ \\
\hline 1 & $\begin{array}{l}\text { Age } \\
<25 \text { Years } \\
\text { 25-35 Years } \\
>35 \text { Years }\end{array}$ & $\begin{array}{l}5 \\
23 \\
43\end{array}$ & $\begin{array}{l}7 \\
32.4 \\
60.6\end{array}$ \\
\hline 2 & $\begin{array}{l}\text { Gender } \\
\text { Men } \\
\text { Woman }\end{array}$ & $\begin{array}{l}28 \\
6\end{array}$ & $\begin{array}{l}39.4 \\
8.5\end{array}$ \\
\hline 3 & $\begin{array}{l}\text { Tribe } \\
\text { Batak } \\
\text { Malay } \\
\text { Java } \\
\text { Minang } \\
\text { Aceh }\end{array}$ & $\begin{array}{l}28 \\
6 \\
30 \\
4 \\
3\end{array}$ & $\begin{array}{l}39.4 \\
8.5 \\
43.3 \\
5,6 \\
4,2\end{array}$ \\
\hline 4 & $\begin{array}{l}\text { Religion } \\
\text { Islam } \\
\text { Protestant Christian } \\
\text { Catholic Christian } \\
\end{array}$ & $\begin{array}{l}48 \\
18 \\
5\end{array}$ & $\begin{array}{l}67.6 \\
25.4 \\
7\end{array}$ \\
\hline 5 & $\begin{array}{l}\text { Level of education } \\
\text { Primary School } \\
\text { Junior High } \\
\text { High school } \\
\text { Bachelor }\end{array}$ & $\begin{array}{l}4 \\
3 \\
53 \\
11\end{array}$ & $\begin{array}{l}5,6 \\
4,2 \\
74.6 \\
15.5\end{array}$ \\
\hline 6 & $\begin{array}{l}\text { Income / month } \\
\text { <Rp. 1,000,000 Rp. } 1,000,000- \\
\text { Rp. } 3,000,000 \\
>\text { Rp. } 3,000,000\end{array}$ & $\begin{array}{l}33 \\
30 \\
8\end{array}$ & $\begin{array}{l}46.5 \\
42.3 \\
11.3\end{array}$ \\
\hline 7 & $\begin{array}{l}\text { Relationship with the elderly } \\
\text { Child } \\
\text { Nephew } \\
\text { Sibling }\end{array}$ & $\begin{array}{l}67 \\
3 \\
1\end{array}$ & $\begin{array}{l}94.4 \\
4,2 \\
1.4\end{array}$ \\
\hline 8 & $\begin{array}{l}\text { Illness Elderly } \\
\text { Ulcer } \\
\text { Cataract } \\
\text { Drops of Mellitus } \\
\text { Osteoporosis } \\
\text { Uric acid } \\
\text { Rheumatoid Arthritis } \\
\text { Hypertension } \\
\text { Tuberculosis }\end{array}$ & $\begin{array}{l}18 \\
7 \\
11 \\
9 \\
8 \\
5 \\
10 \\
3\end{array}$ & $\begin{array}{l}25.4 \\
9.9 \\
15 \\
5 \\
12.7 \\
11.3 \\
7 \\
14.1 \\
4,2\end{array}$ \\
\hline
\end{tabular}

Based on the results of research conducted on 71 respondents using 3 categories, it was found that the majority of respondents had good knowledge as many as 43 respondents (60.6), while 
sufficient knowledge was 25 respondents (35.2\%), and as many as 3 respondents $(4.2 \%)$ have less knowledge about fall prevention.

Table 2. Family Knowledge about the Prevention of Fall in the Elderly in Pahlawan Binjai Village

\begin{tabular}{llll}
\hline No. & Family Knowledge & F & $(\%)$ \\
\hline & Good & 43 & 60.6 \\
Moderate & 25 & 35.2 \\
Poor & 3 & 4,2 \\
\hline
\end{tabular}

Respondents' knowledge is identified with 10 statements, namely 1 statement to identify the meaning of falling, 2 statements to identify risk factors for falls, 2 statements to identify causes of falls, 1 statement to identify environmental factors that are often associated with elderly accidents, 2 statements to identify situational factors that precipitate falls, 1 statement to identify fall complications, and 1 statement to identify fall prevention efforts.

Table 3. Distribution of frequency and percentage of family knowledge about falling incidence prevention among the elderly in Pahlawan Binjai Village.

\begin{tabular}{llcc}
\hline No. & \multicolumn{1}{c}{ Statement } & Right & Wrong \\
\hline 1 & $\begin{array}{l}\text { Fall is an event that results in the elderly suddenly lying down, sitting on } \\
\text { the floor / lower place with or without losing consciousness }\end{array}$ & $61(85.9 \%)$ & $10(14.1 \%)$ \\
\hline 2 & The elderly who use a walking aid are not at risk of further falls & $40(69 \%)$ & $31(43.7 \%)$ \\
\hline 3 & A decrease in vision and hearing is one of the risks of falling & $49(69 \%)$ & $22(31 \%)$ \\
\hline 4 & When the elderly walk, they may fall because they lie too long & $49(69 \%)$ & $162(22.5 \%)$ \\
\hline 5 & Headaches cannot cause falls in the elderly & $55(77.5 \%)$ \\
\hline 6 & The use of squat toilets is very good for the elderly & $34(47.9 \%)$ & $37(52.1 \%)$ \\
\hline 7 & The fall will not occur in the elderly who can walk without a walker & $36(50.7 \%)$ & $35(49.3 \%)$ \\
\hline 8 & The lights in the home should be blinding to prevent falling on the elderly & $45(63.4 \%)$ & $22(31 \%)$ \\
\hline 9 & Fall on the elderly will cause complications such as death & $60(63.4 \%)$ & $11(15.5 \%)$ \\
\hline 10 & Making a handle in the bathroom is an effort to prevent falls & $68(95.8 \%)$ & $3(4.2 \%)$
\end{tabular}

Based on the results of research on 71 respondents, it was found that all respondents had a positive attitude about falling prevention. 
Table 4. Distribution of frequency and percentage of family attitudes regarding the prevention of falls among the elderly in Pahlawan Binjai Village

\begin{tabular}{|c|c|c|c|c|c|}
\hline No & Questions & SS & $\mathrm{S}$ & $\mathrm{TS}$ & STS \\
\hline 1 & $\begin{array}{l}\text { The family takes the elderly to go to the health service to have } \\
\text { their health checked }\end{array}$ & $\begin{array}{c}42 \\
(59.2 \%)\end{array}$ & $\begin{array}{l}29 \\
(40.8 \%)\end{array}$ & $\begin{array}{l}0 \\
(0 \%)\end{array}$ & $\begin{array}{l}0 \\
(0 \%)\end{array}$ \\
\hline 2 & The family makes the house lighting bright with the flag to dazzle & $\begin{array}{c}7 \\
(9.9 \%)\end{array}$ & $\begin{array}{c}18 \\
(25.4 \%)\end{array}$ & $\begin{array}{c}35 \\
(49.3 \%)\end{array}$ & $\begin{array}{c}11 \\
(15.5)\end{array}$ \\
\hline 3 & The family let Lanisa do strenuous activities & $\begin{array}{c}1 \\
(1.4 \%)\end{array}$ & $\begin{array}{c}1 \\
(1.4 \%)\end{array}$ & $\begin{array}{c}3 \\
5(49.3 \%)\end{array}$ & $\begin{array}{c}34 \\
(47.9 \%)\end{array}$ \\
\hline 4 & $\begin{array}{l}\text { The family places household equipment in such a way that it does } \\
\text { not interfere with the road or the place where the elderly carry out } \\
\text { activities every day }\end{array}$ & $\begin{array}{c}45 \\
(63.4 \%)\end{array}$ & $\begin{array}{c}23 \\
(32.4 \%)\end{array}$ & $\begin{array}{c}2 \\
(2.8 \%)\end{array}$ & $(1.4 \%)$ \\
\hline 5 & The family brushes the bathroom to make it slippery & $\begin{array}{c}57 \\
(80.3 \%)\end{array}$ & $\begin{array}{c}13 \\
(18.3 \%)\end{array}$ & $\begin{array}{c}0 \\
(0 \%)\end{array}$ & $\begin{array}{c}1 \\
(1.4 \%)\end{array}$ \\
\hline 6 & The family does not need to make a handle on the bathroom wall & $\begin{array}{c}1 \\
(1.4 \%)\end{array}$ & $\begin{array}{c}9 \\
(12.7 \%)\end{array}$ & $\begin{array}{c}48 \\
(67.6 \%)\end{array}$ & $\begin{array}{c}13 \\
(18.3 \%)\end{array}$ \\
\hline 7 & Families pay attention to the ability of the elderly to walk & $\begin{array}{c}32 \\
(45.1 \%)\end{array}$ & $\begin{array}{c}39 \\
(54.9 \%)\end{array}$ & $\begin{array}{c}0 \\
(0 \%)\end{array}$ & $\begin{array}{c}0 \\
(0 \%)\end{array}$ \\
\hline 8 & $\begin{array}{l}\text { Families continue to use unsafe household appliances such as } \\
\text { weathered equipment }\end{array}$ & $\begin{array}{c}8 \\
(11.3 \%)\end{array}$ & $\begin{array}{c}0 \\
(0 \%)\end{array}$ & $\begin{array}{c}35 \\
(49.3 \%)\end{array}$ & $\begin{array}{c}28 \\
(39.4 \%)\end{array}$ \\
\hline 9 & The family does not facilitate the elderly when defecating & $\begin{array}{c}6 \\
(8.5 \%)\end{array}$ & $\begin{array}{c}9 \\
(12.7 \%)\end{array}$ & $\begin{array}{c}47 \\
(66.2 \%)\end{array}$ & $\begin{array}{c}9 \\
(12.7 \%)\end{array}$ \\
\hline 10 & $\begin{array}{l}\text { The family sees and assesses the body balance of the elderly in } \\
\text { moving to move places or positions }\end{array}$ & $\begin{array}{c}22 \\
(31 \%)\end{array}$ & $\begin{array}{c}44 \\
(62 \%)\end{array}$ & $\begin{array}{c}4 \\
(5.6 \%)\end{array}$ & $\begin{array}{c}1 \\
(1.4 \%)\end{array}$ \\
\hline 11 & $\begin{array}{l}\text { The family knows the drugs that the elderly are taking that can } \\
\text { cause falls }\end{array}$ & $\begin{array}{c}28 \\
(39.4 \%)\end{array}$ & $\begin{array}{c}36 \\
(50.7 \%)\end{array}$ & $\begin{array}{c}5 \\
(7 \%)\end{array}$ & $\begin{array}{c}2 \\
2.8 \%)\end{array}$ \\
\hline 12 & Families do not need to be with the elderly when traveling & $\begin{array}{c}1 \\
(1.4 \%)\end{array}$ & $\begin{array}{c}2 \\
(2.8 \%)\end{array}$ & $\begin{array}{c}47 \\
(66.2 \%)\end{array}$ & $\begin{array}{c}21 \\
(29.6 \%)\end{array}$ \\
\hline 13 & $\begin{array}{l}\text { The family cleans the floor of the house so that it is not slippery } \\
\text { which can cause the elderly to slip }\end{array}$ & $\begin{array}{c}45 \\
(63.4 \%)\end{array}$ & $\begin{array}{c}23 \\
(32.4 \%)\end{array}$ & $\begin{array}{c}1 \\
(1.4 \%)\end{array}$ & $\begin{array}{c}2 \\
(2.8 \%)\end{array}$ \\
\hline 14 & The family put a thick doormat in the house & $\begin{array}{c}17 \\
(23.9 \%)\end{array}$ & $\begin{array}{c}37 \\
(52.1 \%)\end{array}$ & $\begin{array}{c}1 \\
(21.4 \%)\end{array}$ & $\begin{array}{r}2 \\
(2.8 \%)\end{array}$ \\
\hline 15 & The family makes the bathroom door easy to open & $\begin{array}{c}38 \\
(53.5 \%)\end{array}$ & $\begin{array}{c}33 \\
(46.5 \%)\end{array}$ & $\begin{array}{c}0 \\
(0 \%)\end{array}$ & $\begin{array}{c}0 \\
(0 \%)\end{array}$ \\
\hline
\end{tabular}


Table 5. Family attitudes regarding the prevention of falls in the elderly in the Kelurahan Hero Binjai.

\begin{tabular}{lll}
\hline Family Attitude & F & $(\%)$ \\
\hline Positive & 71 & 100 \\
\hline
\end{tabular}

The respondent's attitude was identified with 15 statements, namely 11 identifying statements about risk factor identification, 2 statements to identify about assessing balance and gait, and 2 statements to identify about regulating / overcoming situational factors.

\section{Conclusion}

Based on the results of the research and the discussion description, it can be concluded that the research conducted in April on 71 respondents regarding family knowledge and attitudes about the prevention of falls in the elderly in Pahlawan Binjai Village illustrates the majority of respondents $(60.6 \%)$ have good knowledge in preventing incidents falls in the elderly. While the family attitude about falling prevention, the whole family (100\%) had a positive attitude in falling prevention. This shows that the family is ready to act to prevent falls.

\section{Suggestion}

a. In the data collection process, a better approach was sought with the respondents so that in providing cooperative respondent information and research samples were fulfilled.

b. In nursing practice, it is expected that nurses pay attention to the family and encourage families to modify the environment so that the elderly does not fall and reduce the risk of falling and nurses remain effective and active in providing education and counseling to families regarding knowledge about falling prevention.

c. In future studies, it is hoped that more research respondents will be used so that the results are more representative. In addition, it is hoped that further nursing researchers will examine other factors that influence knowledge and attitudes in preventing falls. 
d. Families who have elderly people at home are expected to be able to look after and care for the elderly so that the incidence of falls can be reduced or prevented and should have good behavior in preventing falls in the elderly.

\section{Acknowledgement}

Authors would like to thank to all respondents who provide the researchers with valuable data during the data collection.

\section{Conflict of Interest}

There is no conflict of interest in this research result

\section{REFERENCES}

[1] Darmojo, BR, \& Martono, HH (2004). Geriatric textbooks; Elderly health sciences, Jakarta: Publishing House, Faculty of Medicine, University of Indonesia.

[2] Maryam, SM (2009). The effect of physical balance on the body balance of the elderly in the Jakarta Regional Tresna Werdha Social Home. Opened on October 4, 2011 fromhttp://digilib.ui.ac.id

[3] Maryam, SR, Ekasari, FM, Rosidawati, Jubaedi, A., \& Batubara, I. (2008). Know the elderly and their care. Jakarta: Salemba Medika.

[4] Narayani, I. (2008). The relationship between the level of family knowledge and family attitudes in providing daily living activities (ADL) care at the village house of Tanjungrejo Margoyoso Pati. Opened on October 4, 2011 fromhttp://etd.eprints.ums.ac.id

[5] Nugroho, W. (2000). Gerontic nursing. Jakarta: Book Medical Publishers EGC

[6] Nugroho, W. (2008). Gerontic \& Geriatric. Jakarta: Book Medical Publishers EGC.

[7] Probosuseno. (2006). Why Elderly People Often Fall Down Suddenly. Opened on October 4, 2011 fromwww.republika.co.id

[8] Purwanto, H. (1999). Introduction to human behavior for nursing. Jakarta: Book Medical Publishers EGC. 
[9] Susanti, T. (2009). The relationship between the level of family knowledge and the attitudes of elderly families in falling prevention

at home in Dusun Gamping Kidul Ambar Ketawang Sleman Yogyakarta. Opened on October 14, 2011 fromhttp://publikasi.umy.ac.id 